\title{
Synthesis and biological evaluation of carbon-11- and fluorine-18-labeled 2-oxoquinoline derivatives for type 2 cannabinoid receptor positron emission tomography imaging ${ }^{\text {t3 }}$
}

\author{
Nele Evens ${ }^{\mathrm{a}}$, Giulio G. Muccioli ${ }^{\mathrm{b}}$, Nele Houbrechts ${ }^{\mathrm{a}}$, Didier M. Lambert ${ }^{\mathrm{b}}$, \\ Alfons M. Verbruggen ${ }^{\mathrm{a}}$, Koen Van Laere ${ }^{\mathrm{c}}$, Guy M. Bormans ${ }^{\mathrm{a}, *}$ \\ ${ }^{a}$ Laboratory for Radiopharmacy, K.U. Leuven, 3000 Leuven, Belgium \\ ${ }^{\mathrm{b}}$ Unité de Chimie Pharmaceutique et de Radiopharmacie, U.C. Louvain, 1200 Bruxelles, Belgium \\ ${ }^{\mathrm{c}}$ Division of Nuclear Medicine, K.U. Leuven, 3000 Leuven, Belgium \\ Received 10 December 2008; received in revised form 14 January 2009; accepted 15 January 2009
}

\begin{abstract}
Introduction: The type 2 cannabinoid $\left(\mathrm{CB}_{2}\right)$ receptor is part of the endocannabinoid system and has been suggested as a mediator of several central and peripheral inflammatory processes. Imaging of the $\mathrm{CB}_{2}$ receptor has been unsuccessful so far. We synthesized and evaluated a carbon-11- and a fluorine-18-labeled 2-oxoquinoline derivative as new PET tracers with high specificity and affinity for the $\mathrm{CB}_{2}$ receptor. Methods: Two 2-oxoquinoline derivatives were synthesized and radiolabeled with either carbon-11 or fluorine-18. Their affinity and selectivity for the human $\mathrm{CB}_{2}$ receptor were determined. Biological evaluation was done by biodistribution, radiometabolite and autoradiography studies in mice.

Results: In vitro studies showed that both compounds are high affinity $\mathrm{CB}_{2}$-specific inverse agonists. Biodistribution study of the tracers in mice showed a high in vivo initial brain uptake and fast brain washout, in accordance with the low $\mathrm{CB}_{2}$ receptor expression levels in normal brain. A persistently high in vivo binding to the spleen was observed, which was inhibited by pretreatment with two structurally unrelated $\mathrm{CB}_{2}$ selective inverse agonists. In vitro autoradiography studies with the radioligands confirmed $\mathrm{CB}_{2}$-specific binding to the mouse spleen. Conclusion: We synthesized two novel $\mathrm{CB}_{2}$ receptor PET tracers that show high affinity/selectivity for $\mathrm{CB}_{2}$ receptors. Both tracers show favourable characteristics as radioligands for central and peripheral in vivo visualization of the $\mathrm{CB}_{2}$ receptor and are promising candidates for primate and human $\mathrm{CB}_{2}$ PET imaging.
\end{abstract}

(C) 2009 Elsevier Inc. All rights reserved.

Keywords: $\mathrm{CB}_{2}$ receptor; PET; 2-oxoquinolines

\section{Introduction}

The type 2 cannabinoid receptor $\left(\mathrm{CB}_{2}\right.$ receptor) is part of the endocannabinoid system, together with the type 1 cannabinoid receptor $\left(\mathrm{CB}_{1}\right.$ receptor), endogenous ligands, transporters and enzymes. Most research has focused on the $\mathrm{CB}_{1}$ receptor, which is responsible for the psychoactive

\footnotetext{
t5 Research funded by a Ph.D. grant of the institute for the Promotion of Innovation through Science and Technology in Flanders (IWT-Vlaanderen).

* Corresponding author. Tel.: +32 16330447; fax: +32 16330449.

E-mail address: guy.bormans@pharm.kuleuven.be (G.M. Bormans).
}

effects of cannabis and a multitude of other CNS functions (for review, see Ref. [1]) and for which PET radioligands have been developed recently $[2,3]$.

The $\mathrm{CB}_{2}$ receptor is related to the immune system and expressed in the spleen, lymph nodes and Peyer's patches [4]. In normal brain, only low $\mathrm{CB}_{2}$ receptor expression levels were observed [5]. However, in some pathological conditions, the $\mathrm{CB}_{2}$ receptor is up-regulated. Peripheral $\mathrm{CB}_{2}$ receptor up-regulation has been demonstrated in tumors [6], endometrial inflammation [7] and human and mouse atherosclerotic plaques [8]. In the brain, $\mathrm{CB}_{2}$ receptor upregulation is linked to neuroinflammation [9] and was observed in the spinal cord of a mouse model for 
amyotrophic lateral sclerosis [10], plaques of demyelination in multiple sclerosis patients [11], but also in a rat stroke model [12] and on senile amyloid plaques in Alzheimer patients [13]. The $\mathrm{CB}_{2}$ receptor seems to play an important role in the regulation of several biological processes, such as bone modeling [14], skin cancer development [15] and immunity [16].

To date, a number of nonselective tritiated radioligands such as $\left[{ }^{3} \mathrm{H}\right] \mathrm{CP} 55,940$ or $\left[{ }^{3} \mathrm{H}\right]$ WIN55,212 with affinity for the human $\mathrm{CB}_{2}$ receptor are available for in vitro use. Also, synthesis of a near-infrared dye-labeled $\mathrm{CB}_{2}$ receptor ligand for noninvasive in vivo imaging was reported [17]. We recently described the development of a carbon-11-labeled $\mathrm{CB}_{2}$ selective PET tracer, which did not penetrate the bloodbrain barrier (BBB) [18]. Therefore, the use of this tracer will be limited to peripheral visualization of the $\mathrm{CB}_{2}$ receptor. The goal of this recent study was to develop a tracer which crosses the BBB in order to enable the future visualization of $\mathrm{CB}_{2}$ receptor up-regulation in the above-described neuroinflammation pathologies.

In the present study, we have synthesized and studied the biological behaviour of carbon-11- or fluorine-18-labeled 2oxoquinolines as PET tracers for in vivo visualization of the $\mathrm{CB}_{2}$ receptor.

\section{Materials and methods}

\subsection{General conditions}

All reagents and solvents were purchased from Aldrich (Steinheim, Germany), Acros (Geel, Belgium) or ABCR (Karlsruhe, Germany), and were used without further purification.

${ }^{1} \mathrm{H}$ NMR spectra were recorded on a Bruker AVANCE 300-MHz spectrometer (Bruker AG, Faellanden, Switzerland) using $\mathrm{CDCl}_{3}$ or $\mathrm{DMSO}-\mathrm{d}_{6}$ as solvent. Chemical shifts are reported in parts per million relative to tetramethylsilane $(\delta=0)$. Coupling constants are reported in Hertz. Splitting patterns are defined by s (singlet), d (doublet), dd (double doublet), $\mathrm{t}$ (triplet) or $\mathrm{m}$ (multiplet). High-performance liquid chromatography (HPLC) purification and analysis were performed on a Merck Hitachi L6200 intelligent pump (Hitachi, Tokyo, Japan) connected to a UV spectrometer (Waters 2487 dual $\gamma$ absorbance detector) set at $254 \mathrm{~nm}$. Radioactivity in the HPLC eluate was detected using a 2-in. $\mathrm{NaI}(\mathrm{Tl})$ scintillation detector connected to a single-channel analyzer. Data were acquired and analyzed using the RaChel (Lablogic, Sheffield, UK) or GINA Star (Raytest, Straubenhardt, Germany) data acquisition system. Quantification of radioactivity for biodistribution and radiometabolite studies was done using a gamma counter [3-in. $\mathrm{NaI}(\mathrm{Tl})$ well crystal] coupled to a multichannel analyzer and mounted in a sample changer (Wallac 1480 Wizard 3 in., Wallac, Turku, Finland). The values are corrected for background radiation and physical decay during counting. Mass measurement was performed on a time-of-flight mass spectrometer (LCT, Micromass, Manchester, UK) equipped with an orthogonal electrospray ionization interface. Accurate mass determination was done by co-infusion with a $10 \mu \mathrm{g} / \mathrm{ml}$ solution of Kryptofix as an internal lock mass. Acquisition and processing of data were done using Masslynx software (version 3.5, Micromass).

\subsection{Synthesis}

Synthesis of Compounds 1, 2, 3, 4, 5 and 6 was based on methods described by Raitio et al. [19] with introduction of small modifications.

\subsubsection{2-Nitro-3-hydroxy-4-methoxybenzaldehyde (1)}

To a mixture of isovanillin $(4.45 \mathrm{~g}, 29.25 \mathrm{mmol})$ in anhydrous dichloromethane $(50 \mathrm{ml})$ at $-70^{\circ} \mathrm{C}, 58.4 \mathrm{ml}$ of a $0.5 \mathrm{M}$ nitronium tetrafluoroborate solution in sulfolane was added and stirred for $1 \mathrm{~h}$. The reaction mixture was allowed to heat up to $-20^{\circ} \mathrm{C}$ and further reacted for $24 \mathrm{~h}$ at $-20^{\circ} \mathrm{C}$. Water $(30 \mathrm{ml})$ was added dropwise and the mixture was allowed to reach room temperature (RT). The reaction mixture was extracted with diethylether $(3 \times 100 \mathrm{ml})$ and the combined diethylether fractions were washed with water $(50 \mathrm{ml})$ and brine $(50 \mathrm{ml})$ and dried over $\mathrm{MgSO}_{4}$. After evaporation of the solvent, the crude reaction product was purified by silica gel column chromatography using hexane/ EtOAc 1:1 as the eluent to yield a yellow oil (3.28 g, 57\%). MS (ES) $)^{-}: m / z=196(\mathrm{M}-\mathrm{H})^{-} .{ }^{1} \mathrm{H}$ NMR (DMSO) $\delta 10.807$ $(1 \mathrm{H}, \mathrm{br} \mathrm{s}), 9.756(1 \mathrm{H}, \mathrm{s}), 7.577\left(1 \mathrm{H}, \mathrm{d},{ }^{3} J_{H-H}=8.4 \mathrm{~Hz}\right), 7.344$ $\left(1 \mathrm{H}, \mathrm{d},{ }^{3} J_{H-H}=8.5 \mathrm{~Hz}\right), 3.988(3 \mathrm{H}, \mathrm{s})$.

\subsubsection{2-Nitro-3-butyloxy-4-methoxybenzaldehyde (2)}

Bromobutane $(6.12 \mathrm{ml}, 57.00 \mathrm{mmol})$ was added dropwise to a mixture of $1(3.20 \mathrm{~g}, 16.23 \mathrm{mmol})$ and potassium carbonate $(7.88 \mathrm{~g}, 56.99 \mathrm{mmol})$ in anhydrous dimethylformamide $(100 \mathrm{ml})$. The reaction mixture was stirred at $100^{\circ} \mathrm{C}$ for $2 \mathrm{~h}$. After filtration and dilution with water $(50 \mathrm{ml})$, the filtrate was extracted with hexane/EtOAc 1:1 $(3 \times 80 \mathrm{ml})$. The combined extracts were washed with water $(60 \mathrm{ml})$ and brine $(60 \mathrm{ml})$, dried over $\mathrm{MgSO}_{4}$ and the solvent was evaporated. Further purification was done by silica gel column chromatography using hexane/EtOAc 19:1 as the eluent to yield 2 as a yellow oil (3.21 g, 78\%). MS (ES) $)^{+}: m / z=254$ $(\mathrm{M}+\mathrm{H})^{+} .{ }^{1} \mathrm{H}$ NMR $\left(\mathrm{CDCl}_{3}\right) \delta 9.789(1 \mathrm{H}, \mathrm{s}), 7.635(1 \mathrm{H}, \mathrm{d}$, $\left.{ }^{3} J_{H-H}=8.6 \mathrm{~Hz}\right), 7.108\left(1 \mathrm{H}, \mathrm{d},{ }^{3} J_{H-H}=8.6 \mathrm{~Hz}\right), 4.113(2 \mathrm{H}, \mathrm{t}$, $\left.{ }^{3} J_{H-H}=6.5 \mathrm{~Hz}\right), 3.999(3 \mathrm{H}, \mathrm{s}), 1.695(2 \mathrm{H}, \mathrm{m}), 1.437(2 \mathrm{H}, \mathrm{m})$, $0.949\left(3 \mathrm{H}, \mathrm{t},{ }^{3} J_{H-H}=7.3 \mathrm{~Hz}\right)$.

\subsubsection{2-Amino-3-butyloxy-4-methoxybenzaldehyde (3)}

To a solution of $2(3.00 \mathrm{~g}, 11.85 \mathrm{mmol})$ in ethanol/acetic acid/water (2:2:1, $80 \mathrm{ml})$, iron powder $(1.98 \mathrm{~g}, 35.45 \mathrm{mmol})$ and concentrated $\mathrm{HCl}(0.6 \mathrm{ml})$ were added. The reaction mixture was refluxed $\left(110^{\circ} \mathrm{C}\right)$ for $15 \mathrm{~min}$, stirred at RT for $1 \mathrm{~h}$, filtrated and water $(60 \mathrm{ml})$ was added to the resulting filtrate, and the solution was extracted with ethylacetate $(3 \times 60 \mathrm{ml})$. The combined ethylacetate extracts were washed with saturated $\mathrm{NaHCO}_{3}(3 \times 60 \mathrm{ml})$ and brine $(60 \mathrm{ml})$, dried 
over $\mathrm{MgSO}_{4}$ and the solvent was evaporated. Further purification was done by silica gel column chromatography using hexane/EtOAc 9:1 to yield $\mathbf{3}$ as a light yellow oil (1.25 g, 47\%). MS (ES) ${ }^{+}: m / z=224(\mathrm{M}+\mathrm{H})^{+} \cdot{ }^{1} \mathrm{H}$ NMR $\left(\mathrm{CDCl}_{3}\right) \delta 9.741(1 \mathrm{H}, \mathrm{s}), 7.216\left(1 \mathrm{H}, \mathrm{d},{ }^{3} J_{H-H}=8.8 \mathrm{~Hz}\right), 6.376$ $\left(1 \mathrm{H}, \mathrm{d},{ }^{3} J_{H-H}=8.8 \mathrm{~Hz}\right), 6.269(2 \mathrm{H}, \mathrm{s}), 3.949\left(2 \mathrm{H}, \mathrm{t},{ }^{3} J_{H-}\right.$ $\left.{ }_{H}=6.7 \mathrm{~Hz}\right), 3.902(3 \mathrm{H}, \mathrm{s}), 1.760(2 \mathrm{H}, \mathrm{m}), 1.512(2 \mathrm{H}, \mathrm{m})$, $0.978\left(3 \mathrm{H}, \mathrm{t},{ }^{3} J_{H-H}=7.3 \mathrm{~Hz}\right)$.

\subsubsection{2-Oxo-7-methoxy-8-butyloxy-1,2-dihydroquinoline-3- carboxylic acid methyl ester (4)}

To a solution of $3(1.22 \mathrm{~g}, 5.46 \mathrm{mmol})$ in methanol (25 ml), dimethyl malonate $(1.89 \mathrm{ml}, 16.54 \mathrm{mmol})$, piperidine $(1.35 \mathrm{ml}, 13.67 \mathrm{mmol})$ and $30 \mu \mathrm{l}$ acetic acid were added. The reaction mixture was refluxed overnight and extracted with ethylacetate $(3 \times 15 \mathrm{ml})$. The combined EtOAc extracts were washed with water $(20 \mathrm{ml})$ and brine (20 ml), dried over $\mathrm{MgSO}_{4}$ and the solvent was evaporated. Purification of $\mathbf{4}$ was done by silica gel column chromatography using dichloromethane: $\mathrm{CH}_{3} \mathrm{OH}$ gradient mixtures $\left(0 \%\right.$ to $\left.1 \% \mathrm{CH}_{3} \mathrm{OH}\right)$ as the eluent yielding 4 as a white solid (0.55 g, 33\%). MS (ES) ${ }^{+}: m / z=306(\mathrm{M}+\mathrm{H}) .{ }^{1} \mathrm{H}$ NMR (DMSO) $\delta 10.984(1 \mathrm{H}, \mathrm{s}), 8.463(1 \mathrm{H}, \mathrm{s}), 7.569\left(1 \mathrm{H}, \mathrm{d},{ }^{3} J_{H-}\right.$ $\left.{ }_{H}=8.9 \mathrm{~Hz}\right), 7.055\left(1 \mathrm{H}, \mathrm{d},{ }^{3} J_{H-H}=8.9 \mathrm{~Hz}\right), 3.964\left(2 \mathrm{H}, \mathrm{t},{ }^{3} J_{H-}\right.$ $\left.{ }_{H}=6.8 \mathrm{~Hz}\right), 3.908(3 \mathrm{H}, \mathrm{s}), 3.783(3 \mathrm{H}, \mathrm{s}), 1.742(2 \mathrm{H}, \mathrm{m}), 1.401$ $(2 \mathrm{H}, \mathrm{m}), 0.918\left(3 \mathrm{H}, \mathrm{t},{ }^{3} J_{H-H}=7.4 \mathrm{~Hz}\right)$.

\subsubsection{2-Oxo-7-methoxy-8-butyloxy-1,2-dihydroquinoline-3- carboxylic acid (5)}

5 (0.50 g, $1.64 \mathrm{mmol})$ was dissolved in ethanol $(19 \mathrm{ml})$ and $\mathrm{HCl} 2 \mathrm{M}$ was added $(12 \mathrm{ml})$. The mixture was stirred at $60^{\circ} \mathrm{C}$ for $7 \mathrm{~h}$, cooled and filtrated. The filter residue was dried under vacuum to give $\mathbf{5}$ as a yellow-white powder (0.26 g, 55\%). MS (ES) $)^{+}: m / z=292(\mathrm{M}+\mathrm{H})$.

\subsubsection{2-Oxo-7-methoxy-8-butyloxy-1,2-dihydroquinoline-3- carboxylic acid cyclohexylamide (6)}

To a solution of $5(0.13 \mathrm{~g}, 0.45 \mathrm{mmol})$ in anhydrous toluene $(10 \mathrm{ml})$, thionylchloride $(0.11 \mathrm{ml}, 1.51 \mathrm{mmol})$ was added. The reaction mixture was refluxed for $3 \mathrm{~h}$. The toluene was evaporated, anhydrous toluene was added again and the evaporation was repeated. The resulting acyl chloride was without further purification dissolved in dichloromethane $(10 \mathrm{ml})$ and added dropwise to a solution of cyclohexylamine $(0.07 \mathrm{~g}, 0.67 \mathrm{mmol})$ and triethylamine $(0.113 \mathrm{~g}, 1.12 \mathrm{mmol})$ in dichloromethane $(10 \mathrm{ml})$. The reaction mixture was stirred for $2 \mathrm{~h}$ at RT. Water $(30 \mathrm{ml})$ was added; the dichloromethane layer was separated from the water layer which was extracted with dichloromethane $(3 \times 20 \mathrm{ml})$. The resulting dichloromethane extracts were washed with brine $(30 \mathrm{ml})$ and dried using $\mathrm{MgSO}_{4}$. The solvent was evaporated and the residue was further purified by silica gel column chromatography using heptane/EtOAc $2: 1$ as the eluent yielding 6 as a white solid $(0.15 \mathrm{~g}, 90 \%) .{ }^{1} \mathrm{H}$ NMR $\left(\mathrm{CDCl}_{3}\right) \delta 9.595\left(1 \mathrm{H}, \mathrm{d},{ }^{3} J_{H-H}=7.8 \mathrm{~Hz}\right), 9.126(1 \mathrm{H}, \mathrm{s})$, $8.859(1 \mathrm{H}, \mathrm{s}), 7.454\left(1 \mathrm{H}, \mathrm{d},{ }^{3} J_{H-H}=8.8 \mathrm{~Hz}\right), 6.932(1 \mathrm{H}, \mathrm{d}$, $\left.{ }^{3} J_{H-H}=8.9 \mathrm{~Hz}\right), 4.145\left(2 \mathrm{H}, \mathrm{t},{ }^{3} J_{H-H}=6.8 \mathrm{~Hz}\right), 3.974(3 \mathrm{H}, \mathrm{s})$,
1.256-2.002 (15H, m), $0.994\left(3 \mathrm{H}, \mathrm{t},{ }^{3} J_{H-H}=7.4 \mathrm{~Hz}\right) . \mathrm{MS}$ $(\mathrm{ES})^{+}$Accurate mass: $\left[\mathrm{C}_{21} \mathrm{H}_{27} \mathrm{~N}_{2} \mathrm{O}_{4}+\mathrm{Na}\right]^{+}$theoretical mass 394.1869 Da and found 394.1829 Da.

\subsubsection{2-Oxo-7-hydroxy-8-butyloxy-1,2-dihydroquinoline-3- carboxylic acid cyclohexylamide (7)}

The reaction proceeded under nitrogen atmosphere. To a solution of diphenylphosphine $(0.12 \mathrm{ml}, 0.7 \mathrm{mmol})$ in anhydrous THF $(0.7 \mathrm{ml})$ at $0^{\circ} \mathrm{C}$, butyllithium $(0.60 \mathrm{ml}$ of a 1.6 $\mathrm{M}$ solution in hexane) was slowly added. The reaction mixture was stirred for $30 \mathrm{~min}$ at RT. A solution of $6(0.20 \mathrm{~g}$, $0.54 \mathrm{mmol})$ in anhydrous THF $(1 \mathrm{ml})$ was slowly added to the reaction mixture, which was further stirred for $3 \mathrm{~h}$. The reaction was quenched by slowly adding water $(10 \mathrm{ml})$ and $\mathrm{NaOH}(\mathrm{pH}>11)$. The reaction mixture was extracted with diethylether $(2 \times 10 \mathrm{ml})$ and the collected diethylether fractions were extracted with $0.1 \mathrm{M} \mathrm{NaOH}(20 \mathrm{ml})$. The combined water fractions were acidified by $\mathrm{HCl} 0.1 \mathrm{M}$ until the solution turned milky white. The solution was extracted with diethylether $(3 \times 20 \mathrm{ml})$ and the combined diethylether fractions washed with water $(20 \mathrm{ml})$ and brine $(20 \mathrm{ml})$, and dried using $\mathrm{MgSO}_{4}$. The excess solvent was evaporated and purification was done by silica gel column chromatography using $\mathrm{CH}_{2} \mathrm{Cl}_{2} / \mathrm{CH}_{3} \mathrm{OH}$ gradient mixtures $(0 \%$ to $1 \%$ $\left.\mathrm{CH}_{3} \mathrm{OH}\right)$ as eluent yielding 7 as a white solid $(0.055 \mathrm{~g}$, 29\%). ${ }^{1} \mathrm{H} \mathrm{NMR}\left(\mathrm{CDCl}_{3}\right) \delta 9.612\left(1 \mathrm{H}, \mathrm{d},{ }^{3} J_{\mathrm{H}-\mathrm{H}}=7.9 \mathrm{~Hz}\right)$, $9.004(1 \mathrm{H}, \mathrm{s}), 8.900(1 \mathrm{H}, \mathrm{s}), 8.848(1 \mathrm{H}, \mathrm{s}), 7.383\left(1 \mathrm{H}, \mathrm{d},{ }^{3} J_{H-}\right.$ $\left.{ }_{H}=8.7 \mathrm{~Hz}\right), 6.947\left(1 \mathrm{H}, \mathrm{d},{ }^{3} J_{H-H}=8.7 \mathrm{~Hz}\right), 4.073\left(2 \mathrm{H}, \mathrm{t},{ }^{3} J_{H-}\right.$ $\left.{ }_{H}=6.8 \mathrm{~Hz}\right), 1.210-2.005(15 \mathrm{H}, \mathrm{m}), 1.007\left(3 \mathrm{H}, \mathrm{t},{ }^{3} J_{H-H}=7.4\right.$ $\mathrm{Hz}$ ). MS (ES) ${ }^{+}$Accurate mass: $\left[\mathrm{C}_{20} \mathrm{H}_{25} \mathrm{~N}_{2} \mathrm{O}_{4}+\mathrm{Na}\right]^{+}$theoretical mass $380.1712 \mathrm{Da}$ and found $380.1724 \mathrm{Da}$.

2.2.8. 2-Oxo-7-fluoroethoxy-8-butyloxy-1,2-dihydroquinoline-3-carboxylic acid cyclohexylamide (8)

To a solution of $7(0.080 \mathrm{~g}, 0.22 \mathrm{mmol})$ in butanone $(6 \mathrm{ml}), \mathrm{NaI}(0.0033 \mathrm{~g}, 0.022 \mathrm{mmol})$, potassium carbonate $(0.046 \mathrm{~g}, 0.33 \mathrm{mmol})$ and fluoroethylbromide (FEtBr; $0.043 \mathrm{~g}, 0.34 \mathrm{mmol}$ ) were added and the reaction mixture was refluxed for $3 \mathrm{~h}$. The solvent was evaporated and purification was done by silica gel column chromatography using heptane/EtOAc gradient mixtures ( $0 \%$ to $5 \%$ EtOAc) yielding 8 as a white solid $(0.037 \mathrm{~g}, 41 \%) .{ }^{1} \mathrm{H}$ NMR $\left(\mathrm{CDCl}_{3}\right)$ $\delta 9.580\left(1 \mathrm{H}, \mathrm{d},{ }^{3} J_{H-H}=8.1 \mathrm{~Hz}\right), 9.125(1 \mathrm{H}, \mathrm{s}), 8.862(1 \mathrm{H}, \mathrm{s})$, $7.439\left(1 \mathrm{H}, \mathrm{d},{ }^{3} J_{H-H}=8.8 \mathrm{~Hz}\right), 6.905\left(1 \mathrm{H}, \mathrm{d},{ }^{3} J_{H-H}=8.8 \mathrm{~Hz}\right)$, $4.813\left(2 \mathrm{H}, \mathrm{dt},{ }^{2} J_{H-F}=47.3 \mathrm{~Hz},{ }^{3} J_{H-H}=4.0 \mathrm{~Hz}\right), 4.370(2 \mathrm{H}, \mathrm{dt}$, $\left.{ }^{3} J_{H-F}=27.8 \mathrm{~Hz},{ }^{3} J_{H-H}=4.0 \mathrm{~Hz}\right), 4.203\left(2 \mathrm{H}, \mathrm{t},{ }^{3} J_{H-H}=6.7 \mathrm{~Hz}\right)$, 1.256-2.004 (15H, m), $0.996\left(3 \mathrm{H}, \mathrm{t},{ }^{3} J_{H-H}=7.4 \mathrm{~Hz}\right) . \mathrm{MS}$ $(\mathrm{ES})^{+}$Accurate mass: $\left[\mathrm{C}_{22} \mathrm{H}_{29} \mathrm{FN}_{2} \mathrm{O}_{4}+\mathrm{Na}\right]^{+}$theoretical mass 427.2003 Da and found 427.2013 Da.

\subsubsection{1-(2,4-Dichlorophenyl)-6-fluoro-N-piperidin-}

1-yl-1,4-dihydroindeno[1,2-c]pyrazole-3-carboxamide (9)

Synthesis was performed according to the methods described by Mussinu et al. [20] yielding 9 as a white solid. ${ }^{1} \mathrm{H}$ NMR $\left(\mathrm{CDCl}_{3}\right) \delta 7.663\left(1 \mathrm{H}, \mathrm{d},{ }^{4} J_{H-H}=2.2 \mathrm{~Hz}\right)$, $7.630\left(1 \mathrm{H}\right.$, br s), $7.549\left(1 \mathrm{H}, \mathrm{d},{ }^{3} J_{H-H}=8.5\right), 7.470(1 \mathrm{H}, \mathrm{dd}$, ${ }^{3} J_{H-H}=8.8 \mathrm{~Hz}$ and $\left.{ }^{4} J_{H-H}=2.2 \mathrm{~Hz}\right), 7.267\left(1 \mathrm{H}, \mathrm{d},{ }^{3} J_{H-}\right.$ 
$\left.{ }_{H}=9.7 \mathrm{~Hz}\right), 6.915-6.949(2 \mathrm{H}, \mathrm{m}), 3.891(2 \mathrm{H}, \mathrm{s}), 2.887(4 \mathrm{H}, \mathrm{t}$, $\left.{ }^{3} J_{H-H}=5.3 \mathrm{~Hz}\right), 1.761(4 \mathrm{H}, \mathrm{m}), 1.441(2 \mathrm{H}, \mathrm{m})$. Accurate mass: $\left[\mathrm{C}_{22} \mathrm{H}_{19} \mathrm{~N}_{4} \mathrm{OCl}_{2} \mathrm{~F}+\mathrm{H}\right]^{+}$theoretical mass $445.0993 \mathrm{Da}$ and found $445.0990 \mathrm{Da}$.

\subsection{Radiosynthesis}

\subsubsection{Synthesis of $\left[{ }^{11} \mathrm{C}\right]-\mathbf{6}$}

2.3.1.1. Synthesis of $\left[{ }^{11} \mathrm{C}\right] \mathrm{CH}_{3} I,\left[{ }^{11} \mathrm{C}\right]$ methyl triflate and $\left[{ }^{11} \mathrm{C}\right]-6$. Carbon-11 was produced in a Cyclone 18/9 cyclotron (IBA, Louvain-la-Neuve, Belgium) in the form of ${ }^{11} \mathrm{CH}_{4}$ by irradiation of a mixture of $\mathrm{N}_{2}$ with $5 \% \mathrm{H}_{2}$ with 18-MeV protons. ${ }^{11} \mathrm{CH}_{4}$ was transferred from the cyclotron target to a home-made synthesis module housed in a lead shielded cabinet where ${ }^{11} \mathrm{CH}_{4}$ was trapped on a column filled with Porapak N (divinylbenzene/vinyl pyrolidone polymer), cooled in liquid nitrogen. The loop was allowed to warm to RT. ${ }^{11} \mathrm{CH}_{4}$ was swept off the column with a stream of helium and was mixed with $\mathrm{I}_{2}$ vapour at $100^{\circ} \mathrm{C}$, after which the mixture passed through a quartz column heated to $650^{\circ} \mathrm{C}$ to yield ${ }^{11} \mathrm{CH}_{3} \mathrm{I}[21] .{ }^{11} \mathrm{CH}_{3} \mathrm{I}$ was used as such or was passed through a column $(150 \times 3 \mathrm{~mm})$ filled with silver triflate $(50-\mathrm{mm}$ silver triflate between two times 50 -mm quartz wool) heated to $180^{\circ} \mathrm{C}$, yielding the more reactive $\left[{ }^{11} \mathrm{C}\right]$ methyl triflate. A stream of helium containing the alkylating agent was bubbled through a solution of $200 \mu \mathrm{g} 7$ and $2-4 \mathrm{mg} \mathrm{Cs}{ }_{2} \mathrm{CO}_{3}$ in $200 \mu \mathrm{l} \mathrm{DMF}$. The reaction mixture was heated during $2 \mathrm{~min}$ at $90^{\circ} \mathrm{C}$, diluted with $1.8 \mathrm{ml} 0.05 \mathrm{M}$ ammonium acetate buffer $\mathrm{pH} 6.9$ containing $40 \%$ ethanol and applied onto a semipreparative XTerra RP18 column $(5 \mu \mathrm{m}, 7.8 \times 150 \mathrm{~mm}$; Waters $)$ which was eluted with $0.05 \mathrm{M}$ ammonium acetate buffer $(\mathrm{pH}=6.9) /$ EtOH $(40: 60 \mathrm{v} / \mathrm{v}, 2 \mathrm{ml} / \mathrm{min})$. With this system, retention time is $14.8 \pm 0.5 \mathrm{~min}$ for $\left[{ }^{11} \mathrm{C}\right]-6(n=9)$.

\subsubsection{Synthesis of $\left[{ }^{18} \mathrm{~F}\right]-\mathbf{8}$}

2.3.2.1. Production of $\left[{ }^{18} \mathrm{~F}\right]$ fluoride. $\left[{ }^{18} \mathrm{~F}\right]$ Fluoride was produced from a $\left[{ }^{18} \mathrm{O}(\mathrm{p}, \mathrm{n}){ }^{18} \mathrm{~F}\right]$ nuclear reaction by irradiation on $97 \%$ enriched $\mathrm{H}_{2}^{18} \mathrm{O}$ (Rotem HYOX18, Rotem Industries, Beer Sheva, Israel) using $18-\mathrm{MeV}$ protons. After irradiation, $\left[{ }^{18} \mathrm{~F}\right] \mathrm{F}^{-}$was separated from $\left[{ }^{18} \mathrm{O}\right] \mathrm{H}_{2} \mathrm{O}$ by trapping on a SepPak Light Accell plus QMA anion exchange cartridge (Waters, Milford, USA), which was previously preconditioned by successive washing with $0.5 \mathrm{M}$ $\mathrm{K}_{2} \mathrm{CO}_{3}$ solution $(10 \mathrm{ml})$ and water $(2 \times 10 \mathrm{ml})$. The $\left[{ }^{18}{\mathrm{~F}] \mathrm{F}^{-}}^{-}\right.$ was eluted from the cartridge with a solution containing $2.47 \mathrm{mg}$ potassium carbonate and $27.9 \mathrm{mg}$ Kryptofix 222 in $0.75 \mathrm{ml}$ of $\mathrm{H}_{2} \mathrm{O}-\mathrm{CH}_{3} \mathrm{CN}(5: 95 \mathrm{v} / \mathrm{v})$ into a reaction vessel. The solution was heated to $96^{\circ} \mathrm{C}$ and the solvent was evaporated with a stream of nitrogen. $\left[{ }^{18} \mathrm{~F}\right] \mathrm{F}^{-}$was further dried by adding $1 \mathrm{ml}$ of anhydrous acetonitrile and subsequent evaporation at $96^{\circ} \mathrm{C}$ with a stream of nitrogen.

2.3.2.2. Synthesis of $\left[{ }^{18} \mathrm{~F}\right]$ fluoroethylbromide and $\left[{ }^{18} \mathrm{~F}\right]$-8. 2-Bromoethyl triflate $\left(\mathrm{BrCH}_{2} \mathrm{CH}_{2} \mathrm{OTf}\right)(5 \mu \mathrm{l})$ in $o$-dichlorobenzene $(0.7 \mathrm{ml})$ was added to the reaction vessel containing dried $\left[{ }^{18} \mathrm{~F}^{-} \mathrm{F}^{-}\right.$and potassium-kryptofix complex [22]. The reaction vial was then heated to $110^{\circ} \mathrm{C}$ and the resulting $\left[{ }^{18} \mathrm{~F}\right]$ fluoroethylbromide $\left(\left[{ }^{18} \mathrm{~F}\right] \mathrm{FEtBr}\right)$ was distilled with a stream of helium and passed through an ascarite column $(6 \times 150 \mathrm{~mm})$ in a reaction vial containing $200 \mu \mathrm{g} 7$ and $2-4 \mathrm{mg} \mathrm{Cs} \mathrm{CO}_{3}$ in $200 \mu \mathrm{l} \mathrm{DMF}$. The reaction mixture was heated at $90^{\circ} \mathrm{C}$ for $10 \mathrm{~min}$, diluted with $1.8 \mathrm{ml}$ ammonium acetate buffer $0.05 \mathrm{M}$ pH 6.9 containing $30 \%$ ethanol and injected on a semipreparative XTerra RP18 column ( $5 \mu \mathrm{m}, 7.8 \times 150 \mathrm{~mm}$; Waters) which was eluted with $0.05 \mathrm{M}$ ammonium acetate buffer $(\mathrm{pH}=6.9) / \mathrm{EtOH}(40: 60$ $\mathrm{v} / \mathrm{v}, 1.8 \mathrm{ml} / \mathrm{min}$ ). With this system, retention time is $15.4 \pm 1.4 \min$ for $\left[{ }^{18} \mathrm{~F}\right]-8(n=4)$.

\subsection{Quality control}

Quality control for $\left[{ }^{11} \mathrm{C}\right]-6$ and $\left[{ }^{18} \mathrm{~F}\right]-8$ using authentic 6 or $\mathbf{8}$ as a reference was done by HPLC on an XTerra RP18 column $(5 \mu \mathrm{m}, 4.6 \times 250 \mathrm{~mm}$, Waters $)$ eluted with $0.05 \mathrm{M}$ ammonium acetate buffer $\mathrm{pH} 6.9 /$ acetonitrile $(40: 60 \mathrm{v} / \mathrm{v}$, $1 \mathrm{ml} / \mathrm{min})$. Using this system, retention time is $12.8 \pm 0.1 \mathrm{~min}$ for $\left[{ }^{11} \mathrm{C}\right]-6(n=5)$ and $11.9 \pm 0.1 \mathrm{~min}$ for $\left[{ }^{18} \mathrm{~F}\right]-8(n=4)$.

\subsection{Partition coefficient}

Twenty-five microliters of a solution of the HPLCisolated $\left[{ }^{11} \mathrm{C}\right]-6$ or $\left[{ }^{18} \mathrm{~F}\right]-8$ was added to a test tube containing $2 \mathrm{ml}$ of 1 -octanol and $2 \mathrm{ml}$ of $0.025 \mathrm{M}$ phosphate buffer $\mathrm{pH}$ 7.4. The test tube was vortexed at RT for $2 \mathrm{~min}$ and then centrifuged at $2700 \times \mathrm{g}$ for $10 \mathrm{~min}$. A $100-\mu 1$ aliquot was taken from the 1-octanol phase and a 900- $\mu 1$ aliquot from the aqueous phase, taking care to avoid cross contamination between the phases. The separate aliquots were transferred into tared vials and the volume added was calculated from the mass of the aliquots and the specific density $(\rho)$ of the phase, assuming that $\rho_{\text {buffer }}=1.000 \mathrm{~g} / \mathrm{ml}$ and $\rho_{1 \text {-octanol }}=0.827 \mathrm{~g} / \mathrm{ml}$. The radioactivity of the aliquots was counted using an automatic $\gamma$ counter. The partition coefficient $(P)$ was calculated as [radioactivity $(\mathrm{cpm} / \mathrm{ml})$ in 1-octanol]/[radioactivity $(\mathrm{cpm} /$ $\mathrm{ml}$ ) in phosphate buffer $\mathrm{pH}$ 7.4].

\subsection{Biodistribution studies}

The experiments in mice were carried out in compliance with the national laws relating to the conduct of animal experimentation and approved by the local animal ethics committee. All biodistribution studies were conducted in male National Murine Research Institute (NMRI) mice (37$50 \mathrm{~g})$. Mice were anesthetized with isoflurane $(2 \%$ in oxygen). The solution of the HPLC-purified product was diluted with saline to a concentration of approximately $90 \mathrm{MBq} / \mathrm{ml}$ or $7.4 \mathrm{MBq} / \mathrm{ml}$ (for $\left[{ }^{11} \mathrm{C}\right]-6$ or $\left[{ }^{18} \mathrm{~F}\right]-8$, respectively). An aliquot of $100 \mu 1$ was injected via a tail vein. The animals were sacrificed by decapitation, and the organs and body parts were dissected and weighed. The activity in the dissected organs and blood was measured 
using a gamma counter. For calculation of total blood, muscle and bone radioactivity, blood, muscle and bone mass were assumed to be $7 \%, 40 \%$ and $12 \%$, respectively, of the body mass $[23,24]$.

\subsection{Plasma and brain metabolites}

The in vivo metabolic stability of the tracers in plasma and brain was studied in male NMRI mice. $9.25 \mathrm{MBq}$ or $0.74 \mathrm{MBq}$ (for $\left[{ }^{11} \mathrm{C}\right]-6$ or $\left[{ }^{18} \mathrm{~F}\right]-8$, respectively) was injected through a tail vein, and the mice were sacrificed by decapitation at 2,10 or $30 \mathrm{~min}$ pi (two to three mice per time point). For determination of plasma metabolites, blood was collected into a BD vacutainer (containing $7.2 \mathrm{mg}$ $\mathrm{K}_{2}$ EDTA; Becton Dickinson, Franklin Lakes, NJ, USA). The samples were then centrifuged at $1837 \times \mathrm{g}$ for $5 \mathrm{~min}$, to separate plasma. Plasma was mixed with $10 \mu \mathrm{l}$ of reference compound $\mathbf{6}$ or $\mathbf{8}$, respectively $(1 \mathrm{mg} / \mathrm{ml})$ and injected onto an Oasis HLB column (Hydrophilic-Lipophilic Balanced; $4.6 \times 20 \mathrm{~mm}$, Waters) [25]. The proteins of the plasma matrix were washed from the Oasis column with $10 \mathrm{ml}$ of water, which was collected as two 5-ml fractions. The outlet of the Oasis column was then connected to an analytical XTerra RP18 column (5 $\mu \mathrm{m}, 4.6 \times 250 \mathrm{~mm}$; Waters), and both columns in series were then eluted using $0.05 \mathrm{M}$ ammonium acetate $\mathrm{pH}$ 6.9/acetonitrile $(30 / 70 \mathrm{v} / \mathrm{v}, 1 \mathrm{ml} / \mathrm{min})$. Brain samples were collected and homogenized in $4 \mathrm{ml}$ of $\mathrm{CH}_{3} \mathrm{CN} /$ $\mathrm{H}_{2} \mathrm{O}(50 / 50 \mathrm{v} / \mathrm{v})$ followed by centrifugation at $1840 \times \mathrm{g}$ for $10 \mathrm{~min}$. The supernatant was treated with $1 \mathrm{ml}$ of $\mathrm{CH}_{3} \mathrm{CN}$ followed by centrifugation as described above. The supernatant is filtered through a $0.2-\mu \mathrm{m}$ filter (Pall Corporation, Ann Arbor, MI, USA) and $1 \mathrm{ml}$ of this solution was mixed with $10 \mu \mathrm{g}$ of reference compound 6 or $\mathbf{8}(1 \mathrm{mg} / \mathrm{ml}$ solution in $\mathrm{CH}_{3} \mathrm{CN}$ ) followed by injection onto an HPLC system which consisted of an XTerra RP18 column $(5 \mu \mathrm{m}$, $4.6 \times 250 \mathrm{~mm}$; Waters) and ammonium acetate buffer $0.05 \mathrm{M} \mathrm{pH} 6.9 /$ acetonitrile 40/60 (v/v) as the mobile phase ( $1 \mathrm{ml} / \mathrm{min})$. After passage through an in-line UV detector, all HPLC eluates were collected as 1-ml fractions and their radioactivity was measured using a gamma counter.

\subsection{Spleen autoradiography}

For ex vivo studies, the spleen of vehicle-pretreated (control) or ligand-pretreated mice was removed $30 \mathrm{~min}$ pi of the tracer $\left(9.25\right.$ or $0.74 \mathrm{MBq}$ for $\left[{ }^{11} \mathrm{C}\right]-6$ or $\left[{ }^{18} \mathrm{~F}\right]-8$, respectively) and washed with saline to remove blood pool activity. The tissues were then quickly frozen in isopentane cooled with liquid nitrogen to $-50^{\circ} \mathrm{C}$ and cut with a cryotome (Shandon Cryotome FSE, Thermo Fisher, Waltham, MA, USA) into 50- $\mu \mathrm{m}$-thick serial sections mounted on slides.

For in vitro studies, the spleen of NMRI mice was removed and sections of $20 \mu \mathrm{m}$ were cut. The tissue was preincubated for $10 \mathrm{~min}$ at RT with TRIS $50 \mathrm{mM} \mathrm{pH} 7.4$ containing $5 \%$ bovine serum albumin (BSA) to remove endogenous ligands. Each slide was incubated with radio- active solution (260 kBq in $200 \mu 1$ TRIS $50 \mathrm{mM} \mathrm{pH} \mathrm{7.4,5 \%}$ BSA) and in the presence/absence of 'cold' ligand (6 or 9 , $10 \mu \mathrm{M})$ for $10 \mathrm{~min}$ at RT and rinsed twice $(2 \times 5 \mathrm{~min})$ with TRIS $50 \mathrm{mM}$ pH 7.4 containing 1\% BSA and 5\% ethanol at $4^{\circ} \mathrm{C}$. After a quick dip in water at RT, the slides were dried.

Autoradiograms were obtained by exposing the slides overnight to a high-performance phosphor screen (CanberraPackard, Meriden, CT, USA). The images were analyzed with Optiquant software (Canberra-Packard) and the radioactivity concentration in the autoradiograms was expressed in digital light units (DLU) per square millimeters.

\subsection{Pretreatment and statistics}

All compounds were dissolved $(0.2 \mathrm{mg} / \mathrm{ml})$ in aqua ad injectabilia containing 10\% DMSO and 5\% Tween 80 . Injection of $1 \mathrm{mg} / \mathrm{kg}$ 'cold' compound was performed intraperitoneally $30 \mathrm{~min}$ before tracer injection. All control animals were pretreated with the same volume of vehicle.

All statistical analyses were performed with the unpaired two-sided Student's $t$ test. A $P$ value of less than .005 was considered statistically significant.

\subsection{Competition binding assay and $\left[{ }^{35} S\right]-G T P \gamma S$ assay}

\subsubsection{Cell culture}

All cell culture media and supplements were obtained from Invitrogen (Merelbeke, Belgium). Transfected $\mathrm{CHO}$ cells stably expressing the human $\mathrm{CB}_{1}$ or $\mathrm{CB}_{2}$ receptors $\left(\mathrm{CHO}-\mathrm{CB}_{1}\right.$ and $\left.\mathrm{CHO}-\mathrm{CB}_{2}\right)$, kindly provided by Euroscreen (Gosselies, Belgium), were maintained using Ham's F12 medium supplemented with $10 \%$ foetal calf serum, $500 \mu \mathrm{g} /$ $\mathrm{ml}$ geneticin G418, $100 \mathrm{IU} / \mathrm{ml}$ penicillin, $100 \mu \mathrm{g} / \mathrm{ml}$ streptomycin, $2.5 \mu \mathrm{g} / \mathrm{ml}$ fungizone/amphotericin $\mathrm{B}$ and $2 \mathrm{mM}$ L-glutamine. At confluence, cells were trypsinized for dilutions. Cells were cultured at $37^{\circ} \mathrm{C}$ in an atmosphere of humidified air and $5 \% \mathrm{CO}_{2}$.

\subsubsection{Membrane preparation}

Cells were lysed in ice-cold homogenization buffer containing $50 \mathrm{mM}$ Tris- $\mathrm{HCl}, \mathrm{pH}$ 7.4. The homogenate was centrifuged at $15,000 \times \mathrm{g}$ for $10 \mathrm{~min}$. The resulting membrane pellet was washed twice under the same conditions, resuspended in the same buffer and frozen $\left(-80^{\circ} \mathrm{C}\right)$ in aliquots until use. Protein content was determined using the Bradford method with bovine serum albumin as standard [26].

\subsubsection{Competition binding assay}

The assay was performed as previously described [27]. Briefly, competition experiments were conducted on $40 \mu \mathrm{g}$ CHO- $\mathrm{CB}_{1}$ or $\mathrm{CHO}-\mathrm{CB}_{2}$ membrane preparation incubated with $1 \mathrm{nM}\left[{ }^{3} \mathrm{H}\right]-\mathrm{SR} 141716 \mathrm{~A}$ (Amersham, Roosendaal, The Netherlands) or $\left[{ }^{3} \mathrm{H}\right]-\mathrm{CP} 55,940$ (NEN Life Sciences, Zaventem, Belgium) for determination of the affinity for $\mathrm{hCB}_{1} \mathrm{R}$ and $\mathrm{hCB}_{2} \mathrm{R}$, respectively, and with decreasing concentrations of various competition ligands, in plastic tubes containing $0.5 \mathrm{ml}$ final volume of binding buffer 
(50 mM Tris- $\mathrm{HCl}, 3 \mathrm{mM} \mathrm{MgCl} 2,1 \mathrm{mM}$ EDTA, $0.5 \%$ bovine serum albumin, $\mathrm{pH}$ 7.4). Nonspecific binding was determined in the presence of $10 \mu \mathrm{M}$ HU 210, a nonselective $\mathrm{CB}_{1} \mathrm{R}$ and $\mathrm{CB}_{2} \mathrm{R}$ agonist (Tocris Bioscience, Bristol, United Kingdom). After incubation for $1 \mathrm{~h}$ at $30^{\circ} \mathrm{C}$, the solutions were filtered through $0.5 \%$ polyethyleneimine-pretreated glass fiber filters (Whatman, Maidstone, UK).

\subsection{4. ${ }^{35}$ S]-GTP $\gamma S$ Assay}

Experiments ( $n=3$, duplicates) were carried out in a 0.5 $\mathrm{ml}$ total volume of buffer $\left(50 \mathrm{mM}\right.$ Tris-HCl, $3 \mathrm{mM} \mathrm{MgCl}_{2}, 1$ mM EDTA, $100 \mathrm{mM} \mathrm{NaCl}, 0.1 \%$ BSA, pH 7.4) containing $20 \mu \mathrm{M}$ GDP, $40 \mu \mathrm{g}$ protein samples from membrane preparation, $0.05 \mathrm{nM}\left[{ }^{35} \mathrm{~S}\right]-\mathrm{GTP} \gamma \mathrm{S}$ (Amersham, Roosendaal, the Netherlands) and test compounds [27]. Tubes were incubated $1 \mathrm{~h}$ at $30^{\circ} \mathrm{C}$ before filtration through nonpretreated glass fiber filters. Nonspecific binding was determined using
$100 \mu \mathrm{M} \operatorname{Gpp}(\mathrm{NH}) \mathrm{p}$. The radioactivity was measured by liquid scintillation.

\subsection{Data analysis}

$\mathrm{IC}_{50}, \mathrm{EC}_{50}$ and efficacy were determined by nonlinear regression analysis performed using GraphPad Prism software (San Diego, CA, USA). $K_{\mathrm{i}}$ values were calculated following the Cheng-Prusoff equation: $K_{\mathrm{i}}=\mathrm{IC}_{50} /\left(1+L / K_{\mathrm{d}}\right)$, where $L$ is the radioligand concentration [28].

\section{Results}

\subsection{Synthesis and radiosynthesis}

The synthesis of reference compounds and precursor is illustrated in Scheme 1. Synthesis of Compounds 1, 2, 3, 4, 5 and $\mathbf{6}$ was based on methods described by Raitio et al.<smiles>COc1ccc(C=O)cc1O</smiles>

isovanillin<smiles>COc1ccc(C=O)c([N+](=O)[O-])c1O</smiles>

1<smiles>COc1ccc(C=O)c([N+](=O)[O-])c1OC</smiles>

$\underline{2}$

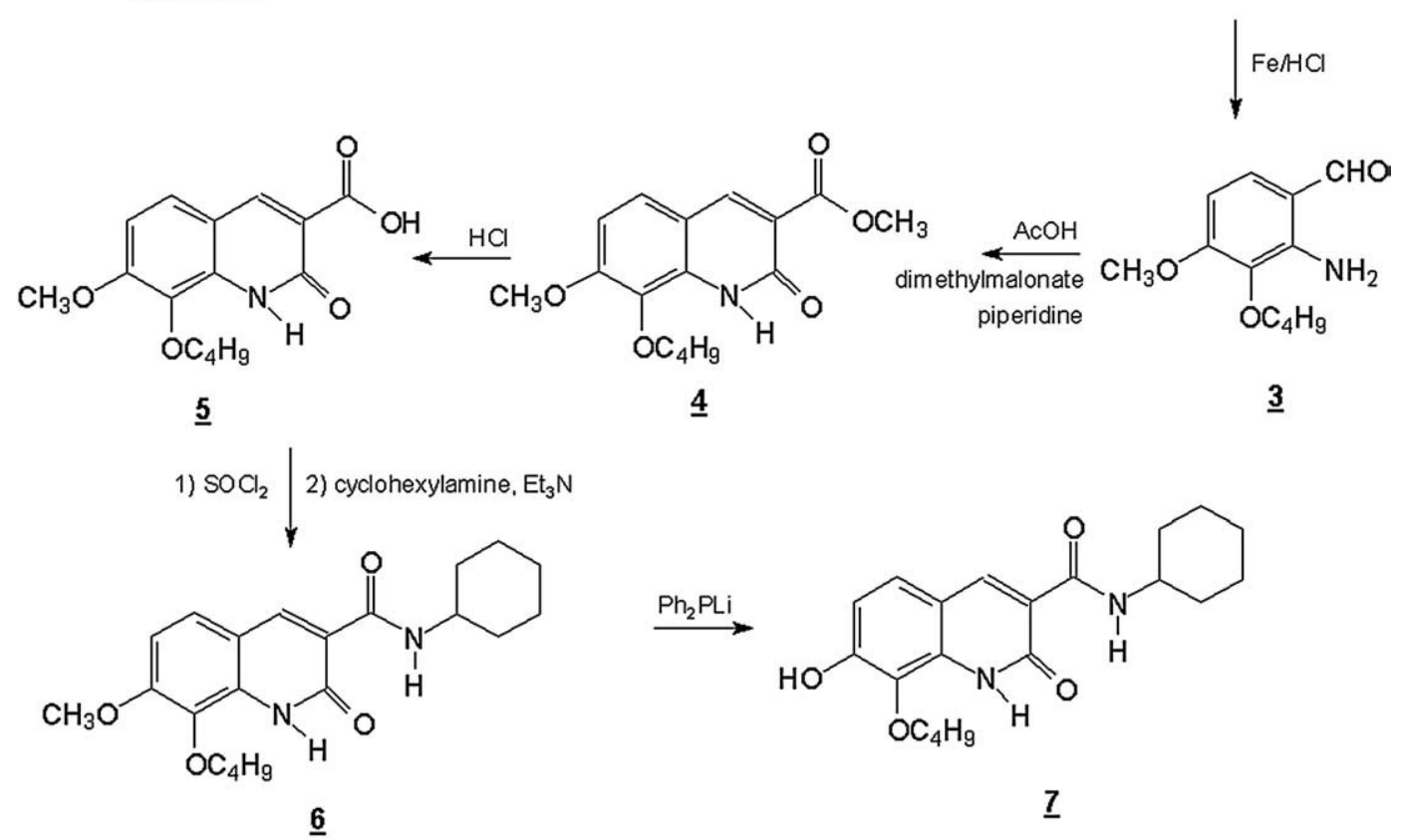<smiles>CCOc1c(OCCF)ccc2cc(C(=O)NC3CCCCC3)c(=O)[nH]c12</smiles> 
[19]. Compound 6 was demethylated using lithium diphenylphosphide as a dealkylating agent. This method provides selective dealkylation of the methoxy group, as such avoiding cleavage of the butyloxy group [29]. Compound 8 was synthesized by reacting 7 with $\mathrm{FEtBr}$ in basic conditions.

Radiosynthesis of $\left[{ }^{11} \mathrm{C}\right]-6$ was performed by bubbling $\left[{ }^{11} \mathrm{C}\right] \mathrm{CH}_{3} \mathrm{I}$ or $\left[{ }^{11} \mathrm{C}\right]$ methyl triflate through a solution of 7 in DMF in basic conditions (Scheme 2). When the reaction was done at RT (using $\left[{ }^{11} \mathrm{C}\right] \mathrm{CH}_{3} \mathrm{I}$ ), a low radiochemical yield of $4.2 \%$ was obtained. However, the radiochemical yield after heating the reaction mixture for $2 \mathrm{~min}$ at $90^{\circ} \mathrm{C}$ was $28 \pm 13 \%$ (average of 17 labeling reactions, \% relative to starting ${ }^{11} \mathrm{CH}_{3} \mathrm{I}$ activity) or $32 \pm 11 \%$ (average of seven labeling reactions, \% relative to starting ${ }^{11} \mathrm{CH}_{3}$ triflate activity) with a specific activity around $37,000 \mathrm{GBq} / \mathrm{mmol}$ and a radiochemical purity $>99 \%$. Using $\left[{ }^{11} \mathrm{C}\right]$ methyl triflate as alkylating agent does not seem to provide any advantage over using $\left[{ }^{11} \mathrm{C}\right] \mathrm{CH}_{3} \mathrm{I}$.

Radiolabeling of $\mathbf{8}$ was done by reacting $\left[{ }^{18} \mathrm{~F}\right] \mathrm{FEtBr}$ with 7 in DMF in the presence of $\mathrm{Cs}_{2} \mathrm{CO}_{3}$ (Scheme 2). At RT, no formation of $\left[{ }^{18} \mathrm{~F}\right]-8$ was observed. After $10 \mathrm{~min}$ at $90^{\circ} \mathrm{C}$, an average yield of $8.7 \%$ was obtained ( $n=4$, EOS). Further heating did not improve the yield. The radiochemical purity was $>99 \%$ with a specific activity around $10,000 \mathrm{GBq} / \mathrm{mmol}$.

\subsection{Partition coefficient, polar surface area}

The $\log P$, calculated $\log P$ and tPSA of $\left[{ }^{11} \mathrm{C}\right]-6$ and $\left[{ }^{18} \mathrm{~F}\right]-8$ are stated in Table $1[30,31]$. For comparison, the calculated $\log P$ and tPSA are given for 2-oxo-7-methoxy-8-pentyloxy1,2-dihydroquinoline-3-carboxylic acid cyclohexylamide
Table 1

$\log P$, calculated $\log P$ and tPSA of $\left[{ }^{11} \mathrm{C}\right]-6,\left[{ }^{18} \mathrm{~F}\right]-8$ and reference compound $\mathbf{1 0}$

\begin{tabular}{llll}
\hline Compound & $\log P$ & Calculated $\log P$ & tPSA $\left(\AA^{2}\right)$ \\
\hline$\left[{ }^{11} \mathrm{C}\right]-\mathbf{6}$ & $3.9 \pm 0.1$ & $3.5 \pm 0.4$ & 80.42 \\
{$\left[{ }^{18} \mathrm{~F}\right]-\mathbf{8}$} & $3.2 \pm 0.2$ & $3.8 \pm 0.5$ & 80.42 \\
$\mathbf{1 0}$ & - & $4.1 \pm 0.4$ & 80.42 \\
\hline
\end{tabular}

(10), which is a potent $\mathrm{CB}_{2}$ inverse agonist [32] and on which the synthesis of our tracers was based.

\subsection{Affinity studies}

The affinity $\left(K_{\mathrm{i}}\right)$ of $\mathbf{6}$ and $\mathbf{8}$ for the human $\mathrm{CB}_{2}$ receptor was 9.6 and $35.8 \mathrm{nM}$, respectively. They were highly selective towards the $\mathrm{CB}_{1}$ receptor $\left(\mathrm{K}_{\mathrm{i}} \mathrm{hCB}_{1}>1000 \mathrm{nM}\right)$. Both compounds behaved as inverse agonists in a $\left[{ }^{35} \mathrm{~S}\right]-\mathrm{GTP} \gamma \mathrm{S}$ assay displaying a comparable potency $\left(\mathrm{EC}_{50}=11.8 \pm 2.2\right.$ and $12.5 \pm 3.2 \mathrm{nM}$ for $\mathbf{6}$ and $\mathbf{8}$, respectively) and negative efficacy $\left(-69 \%\right.$ and $-78 \%$ relative to basal specific $\left[{ }^{35} \mathrm{~S}\right]-\mathrm{GTP} \gamma \mathrm{S}$ binding for $\mathbf{6}$ and $\mathbf{8}$, respectively).

\subsection{Biodistribution studies}

To determine specific $\mathrm{CB}_{2}$ receptor binding, 9 was used as competing agent. This compound was described by Mussinu et al. [20] to have high affinity for the mouse $\mathrm{CB}_{2}$ receptor $\left(\mathrm{K}_{\mathrm{i}} \mathrm{mCB}_{2}=0.23 \mathrm{nM}\right)$ and good selectivity over the mouse $\mathrm{CB}_{1}$ receptor $\left(\mathrm{K}_{\mathrm{i}} \mathrm{mCB}_{1}=1268 \mathrm{nM}\right)$.

3.4.1. Biodistribution studies of $\left[{ }^{11} \mathrm{C}\right]-\mathbf{6}$ and $\left[{ }^{18} \mathrm{~F}\right]-\mathbf{8}$ in mice The distribution of $\left[{ }^{11} \mathrm{C}\right]-6$ and $\left[{ }^{18} \mathrm{~F}\right]-\mathbf{8}$ in mice was highly similar (Tables 2 and 3). Both compounds were cleared from<smiles>CCOc1c(O)ccc2cc(C(=O)NC3CCCCC3)c(=O)[nH]c12</smiles>

$\underline{5}$ $10 \min 90^{\circ} \mathrm{C} \mid \begin{aligned} & {\left[{ }^{18} \mathrm{~F}\right] \mathrm{FEEtBr}} \\ & \mathrm{Cs}_{2} \mathrm{CO}_{3} \\ & \mathrm{DMF}\end{aligned}$<smiles>O=C(NC1CCCCC1)c1cc2ccc(OCC(F)F)c(OCCCCCCCC(F)F)c2[nH]c1=O</smiles>
$\left[{ }^{18} \mathrm{~F}\right\} \underline{6}$<smiles></smiles>

$\left[{ }^{11} \mathrm{C}\right]-\underline{4}$ 
Table 2

Biodistribution of $\left[{ }^{11} \mathrm{C}\right]-6$ in control mice

\begin{tabular}{|c|c|c|c|c|}
\hline \multirow[t]{2}{*}{ Organ } & \multicolumn{2}{|c|}{$\% \mathrm{ID} \pm$ S.D. ${ }^{\mathrm{a}}$} & \multicolumn{2}{|c|}{ SUV \pm S.D. ${ }^{b}$} \\
\hline & $2 \mathrm{~min}$ & $60 \mathrm{~min}$ & $2 \mathrm{~min}$ & $60 \mathrm{~min}$ \\
\hline Kidneys & $12.0 \pm 1.0$ & $4.0 \pm 0.4$ & $6.7 \pm 0.2$ & $2.2 \pm 0.3$ \\
\hline Urine & $0.1 \pm 0.1$ & $0.9 \pm 0.5$ & & \\
\hline Liver & $38.2 \pm 2.7$ & $21.2 \pm 1.0$ & $8.0 \pm 0.4$ & $4.2 \pm 0.2$ \\
\hline Spleen & $0.9 \pm 0.1$ & $0.7 \pm 0.1$ & $3.8 \pm 0.2$ & $3.1 \pm 0.5$ \\
\hline Pancreas & $1.0 \pm 0.3$ & $0.6 \pm 0.2$ & $2.1 \pm 0.5$ & $1.2 \pm 0.2$ \\
\hline Lungs & $1.8 \pm 0.5$ & $1.0 \pm 0.1$ & $2.5 \pm 0.5$ & $1.3 \pm 0.2$ \\
\hline Heart & $1.7 \pm 0.2$ & $0.5 \pm 0.1$ & $4.0 \pm 0.3$ & $1.0 \pm 0.1$ \\
\hline Intestines & $10.5 \pm 0.6$ & $29.8 \pm 3.7$ & & \\
\hline Stomach & $1.6 \pm 0.3$ & $1.8 \pm 1.0$ & & \\
\hline Blood & $7.7 \pm 0.4$ & $4.6 \pm 0.5$ & $1.1 \pm 0.1$ & $0.7 \pm 0.1$ \\
\hline Brain & $1.7 \pm 0.3$ & $0.4 \pm 0.0$ & $1.9 \pm 0.3$ & $0.4 \pm 0.0$ \\
\hline
\end{tabular}

Data are expressed as mean \pm S.D.; $n=4$ per time point.

a Percentage of injected dose calculated as cpm in organ/total cpm recovered.

b Standardized uptake values calculated as (radioactivity in cpm in organ/ weight of the organ in grams)/(total counts recovered/body weight in grams).

plasma via the hepatobiliary system where $\left[{ }^{18} \mathrm{~F}\right]-\mathbf{8}$ was cleared more rapidly [ $14 \%$ vs. $21 \%$ of injected dose (ID) in the liver and $53 \%$ vs. $30 \%$ in the intestines $60 \mathrm{~min}$ pi for $\left[{ }^{18} \mathrm{~F}\right]-8$ and $\left[{ }^{11} \mathrm{C}\right]-\mathbf{6}$, respectively]. Both compounds showed a high initial kidney uptake, but no urinary excretion was observed. Except for the spleen, no major organ retained one of the studied tracers. The uptake of $\left[{ }^{11} \mathrm{C}\right]-6$ in spleen was higher than that of $\left[{ }^{18} \mathrm{~F}\right]-8$ [standardized uptake values (SUVs) of 3.8 and 2.2 at 2 min pi, respectively]. For both tracers, more than $80 \%$ of the initial spleen uptake was still present at $60 \mathrm{~min}$ pi. Bone uptake was high for $\left[{ }^{18} \mathrm{~F}\right]-8$.

\subsubsection{Biodistribution studies of $\left[{ }^{11} \mathrm{C}\right]-6$ in mice pretreated with 6 or 9}

Spleen mass did not vary significantly between the study groups. Pretreatment of the mice with $\mathbf{6}$ or $\mathbf{9}$ thirty minutes

Table 3

Biodistribution of $\left[{ }^{18} \mathrm{~F}\right]-\mathbf{8}$ in control mice

\begin{tabular}{|c|c|c|c|c|c|c|}
\hline \multirow[t]{2}{*}{ Organ } & \multicolumn{3}{|c|}{$\% \mathrm{ID} \pm$ S.D. ${ }^{\mathrm{a}}$} & \multicolumn{3}{|c|}{$\mathrm{SUV} \pm$ S.D. ${ }^{\mathrm{b}}$} \\
\hline & $2 \min$ & $60 \mathrm{~min}$ & $120 \mathrm{~min}$ & $2 \mathrm{~min}$ & $60 \mathrm{~min}$ & $120 n$ \\
\hline (1) & $11.3 \pm 1.2$ & $8 \pm 0.3$ & $2.7 \pm 0.2$ & $6.2 \pm 0.9$ & $1.4 \pm 0.2$ & $1.7+0$ \\
\hline rine & 0 & & & & & \\
\hline ive & $37.5 \pm$ & $13.8=$ & 13.6 & 9 & & $3 \pm 0$ \\
\hline ole & 1 & & 1 & 6 & & $1.9 \pm 0$. \\
\hline & & & & & & $0.6 \pm 0$. \\
\hline un & & & 1 & 2.2 & .0 & $0.7 \pm 0$. \\
\hline & & & .0 & $3.4 \pm 0.4$ & $0.5 \pm 0.0$ & $0.4 \pm 0$ \\
\hline Intestines & $10.8 \pm 1.1$ & $53.1 \pm 2.7$ & $55.2 \pm 2.6$ & & & \\
\hline tomach & $1.4 \pm 0.3$ & $1.0 \pm 0.6$ & $1.0 \pm 0.5$ & & & \\
\hline lood & $5.8 \pm 0.4$ & $2.7 \pm 0.1$ & $2.2 \pm 0.9$ & & & $0.5 \pm 0$ \\
\hline Brai & $1.8 \pm 0.5$ & $0.1 \pm 0.0$ & $0.1 \pm$ & $1.4 \pm 0.3$ & $0.1 \pm 0.0$ & $0.1 \pm 0$ \\
\hline Muscl & & & & & & $0.2 \pm 0$ \\
\hline Bone & $6.3 \pm 0.4$ & $11.3 \pm 1.3$ & $12.0 \pm 3.2$ & $0.5 \pm 0.0$ & $0.9 \pm 0.1$ & $1.0 \pm 0.3$ \\
\hline
\end{tabular}

Data are expressed as mean \pm S.D.; $n=4$ per time point.

a Percentage of ID calculated as cpm in organ/total cpm recovered.

b Standard uptake values calculated as (radioactivity in cpm in organ/ weight of the organ in grams)/(total counts recovered/body weight in grams).
Table 4

Biodistribution of $\left[{ }^{11} \mathrm{C}\right]-6$ in vehicle-pretreated and ligand-pretreated mice

\begin{tabular}{|c|c|c|c|c|c|c|}
\hline \multirow[t]{2}{*}{ Organ } & \multicolumn{3}{|c|}{$\% \mathrm{ID} \pm$ S.D. ${ }^{\mathrm{a}}$} & \multicolumn{3}{|c|}{ SUV \pm S.D. ${ }^{b}$} \\
\hline & $60 \min ^{\mathrm{c}}$ & $60 \min ^{\mathrm{d}}$ & $60 \min ^{\mathrm{e}}$ & $60 \min ^{\mathrm{c}}$ & $60 \min ^{\mathrm{d}}$ & $60 \min ^{\mathrm{e}}$ \\
\hline Kidneys & $3.3 \pm 0.3$ & $3.0 \pm 0.3$ & $3.8 \pm 0.7$ & $1.7 \pm 0.2$ & $1.8 \pm 1.0$ & $1.7 \pm 0.3$ \\
\hline Liver & $20.9 \pm 1.7$ & $21.6 \pm 2.0$ & $20.3 \pm 2.1$ & $3.7 \pm 0.2$ & $3.8 \pm 0.9$ & $3.5 \pm 0.5$ \\
\hline Spleen & $0.8 \pm 0.1$ & $0.3 \pm 0.1^{*}$ & $0.5 \pm 0.0^{*}$ & $2.8 \pm 0.3$ & $0.8 \pm 0.1^{*}$ & $1.4 \pm 0.1^{*}$ \\
\hline Pancreas & $0.6 \pm 0.1$ & $0.8 \pm 0.3$ & $1.0 \pm 0.3$ & $1.1 \pm 0.1$ & $1.4 \pm 0.3$ & $1.2 \pm 0.3$ \\
\hline Lungs & $0.7 \pm 0.1$ & $0.7 \pm 0.1$ & $0.7 \pm 0.0$ & $1.0 \pm 0.1$ & $0.8 \pm 0.2$ & $0.9 \pm 0.1$ \\
\hline Heart & $0.4 \pm 0.0$ & $0.4 \pm 0.0$ & $0.5 \pm 0.3$ & $0.8 \pm 0.1$ & $0.9 \pm 0.4$ & $0.9 \pm 0.5$ \\
\hline Intestines & $29.9 \pm 2.3$ & $33.9 \pm 2.3$ & $25.1 \pm 1.8$ & & & \\
\hline Stomach & $0.9 \pm 0.2$ & $1.0 \pm 0.1$ & $1.1 \pm 0.2$ & & & \\
\hline Blood & $3.7 \pm 0.1$ & $3.6 \pm 0.2$ & $3.9 \pm 0.6$ & $0.5 \pm 0.0$ & $0.6 \pm 0.1$ & $0.5 \pm 0.1$ \\
\hline Brain & $0.4 \pm 0.0$ & $0.4 \pm 0.1$ & $0.4 \pm 0.2$ & $0.3 \pm 0.0$ & $0.3 \pm 0.0$ & $0.3 \pm 0.2$ \\
\hline
\end{tabular}

Data are expressed as mean \pm S.D.; $n=4$ per time point.

a Percentage of injected dose calculated as cpm in organ/total cpm recovered.

b Standardized uptake values calculated as (radioactivity in cpm in organ/weight in grams)/(total counts recovered/body weight in grams)

c Pretreatment vehicle.

d Pretreatment 6.

e Pretreatment 9.

* $P<.005$ with respect to the vehicle pretreated at the same time point.

before tracer injection resulted in significantly lower spleen values, whereas for the other major organs, no difference was observed (Table 4; $P<.005$ ).

The vehicle used for injection of the 'cold' product had no influence on the biodistribution data compared to untreated animals (Tables 2 and 4). When SUVs were compared, both groups were not significantly different $(P<.05$, Bonferroni corrected).

\subsection{Plasma and brain metabolite analysis}

Both tracers were rapidly metabolized in plasma with less than $20 \%$ intact product left at $30 \mathrm{~min}$ pi. Only radiometabolites more polar relative to intact tracer were found. In brain, a relatively small amount $(<20 \%)$ of radiometabolites was observed (Table 5). In view of the large fraction of radiometabolites in plasma, this may be due to the presence of radiometabolites in the vascular compartment of the brain. Further studies using brain perfusion prior to brain radiometabolite quantification will be required to ascertain whether radiometabolites pass the BBB.

Table 5

Fraction of intact tracer of $\left[{ }^{11} \mathrm{C}\right]-6$ and $\left[{ }^{18} \mathrm{~F}\right]-8$ determined in the plasma and brain of normal mice at 2,10 or $30 \mathrm{~min}$ pi

\begin{tabular}{lll}
\hline & {$\left[{ }^{11} \mathrm{C}\right]-6$} & {$\left[{ }^{18} \mathrm{~F}\right]-8$} \\
\hline Plasma & & \\
2 min & $68 \pm 3$ & $86 \pm 5$ \\
$10 \mathrm{~min}$ & $24 \pm 1$ & $41 \pm 6$. \\
$30 \mathrm{~min}$ & $17 \pm 0$ & $12 \pm 1$ \\
Brain & & \\
2 min & $95 \pm 0$ & $92 \pm 1$ \\
10 min & $\mathrm{ND}$ & $82 \pm 3$ \\
\hline
\end{tabular}

Data are expressed as mean \pm S.D.; $n=2$ or 3 per time point. $\mathrm{ND}=$ not determined. 


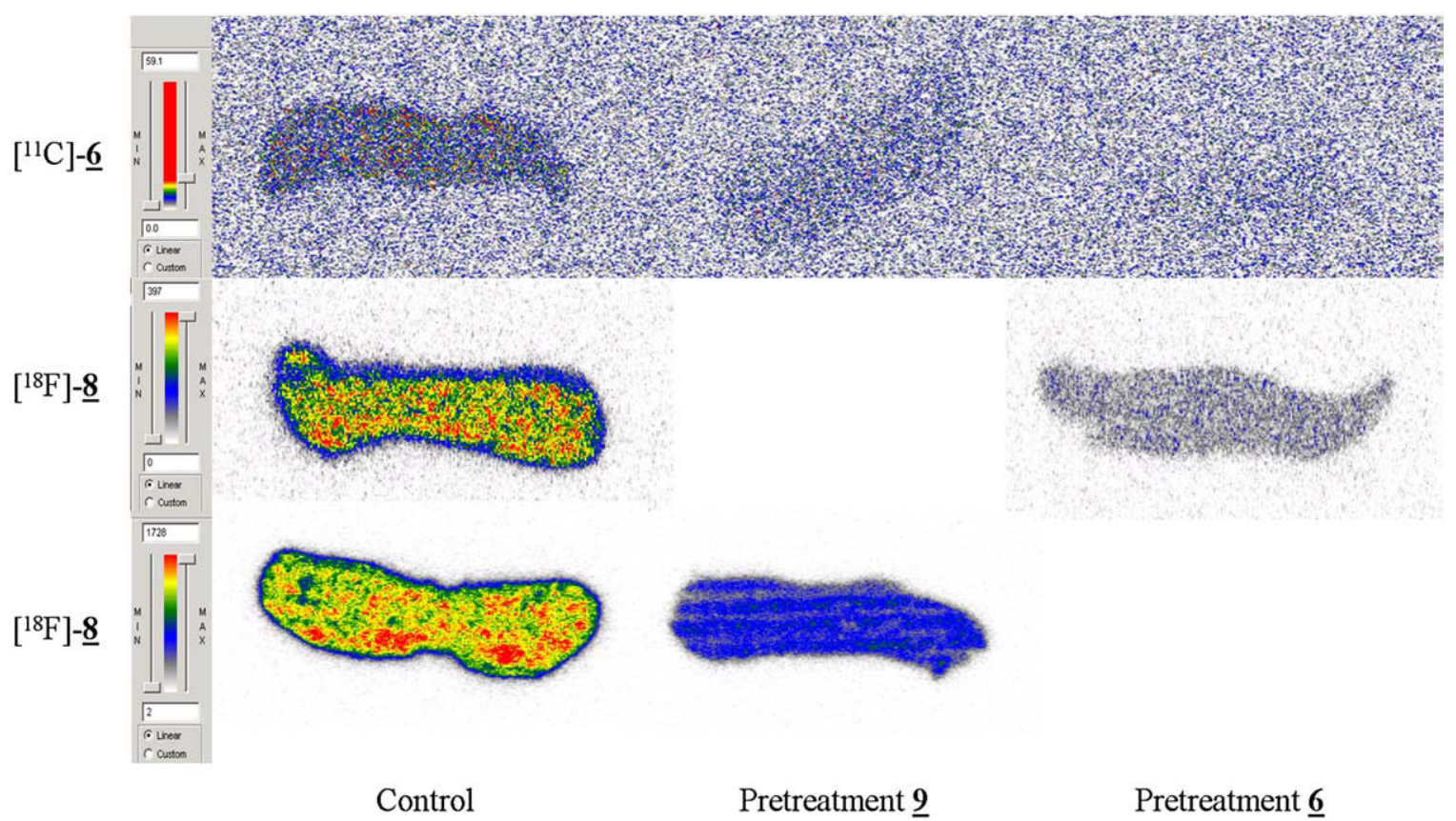

Fig. 1. Ex vivo autoradiography of mouse spleen. Spleen from mice pretreated with vehicle (control) or cold competitor either 9 or $\mathbf{6}$ (pretreated groups) and injected with either $\left[{ }^{11} \mathrm{C}\right]-6$ or $\left[{ }^{18} \mathrm{~F}\right]-8$.

\subsection{Ex vivo and in vitro spleen autoradiography}

Quantification of the autoradiography images (comparison DLU/ $\mathrm{mm}^{2}$ for whole spleen slice) obtained from spleen sections of mice injected with the radiotracers showed that after pretreatment with $\mathbf{9},\left[{ }^{11} \mathrm{C}\right]-\mathbf{6}$ spleen uptake was about one third of the spleen uptake in vehicle-injected mice. This result is in accordance with the biodistribution data where pretreatment with 9 reduced the spleen SUV more than two times at $60 \mathrm{~min}$ pi. Pretreatment with 6 resulted in a 10-15 times lower spleen uptake. However, spleen slices obtained from the mice after pretreatment with 6 were barely distinguishable from the background so that quantification may not be accurate. Even so, pretreatment with $\mathbf{6}$ gave also in the biodistribution study a more pronounced fall in spleen uptake compared to pretreatment with 9. When using $\left[{ }^{18} \mathrm{~F}\right]-\mathbf{8}$, pretreatment with $\mathbf{6}$ inhibited the spleen activity to about one fifth of the spleen uptake in control mice. $\left[{ }^{18} \mathrm{~F}\right]-8$ spleen uptake values obtained after pretreatment with 9 were about threefold lower than control values (Fig. 1).

The ex vivo autoradiography data were confirmed by in vitro autoradiography in which mouse spleen sections were incubated with $\left[{ }^{11} \mathrm{C}\right]-6$ in the presence or absence of $\mathrm{CB}_{2}$ specific compound 6 or $9(10 \mu \mathrm{M})$ (Fig. 2). The presence of $10 \mu \mathrm{M}$ of 6 or 9 resulted in a binding inhibition of about $35 \%$.

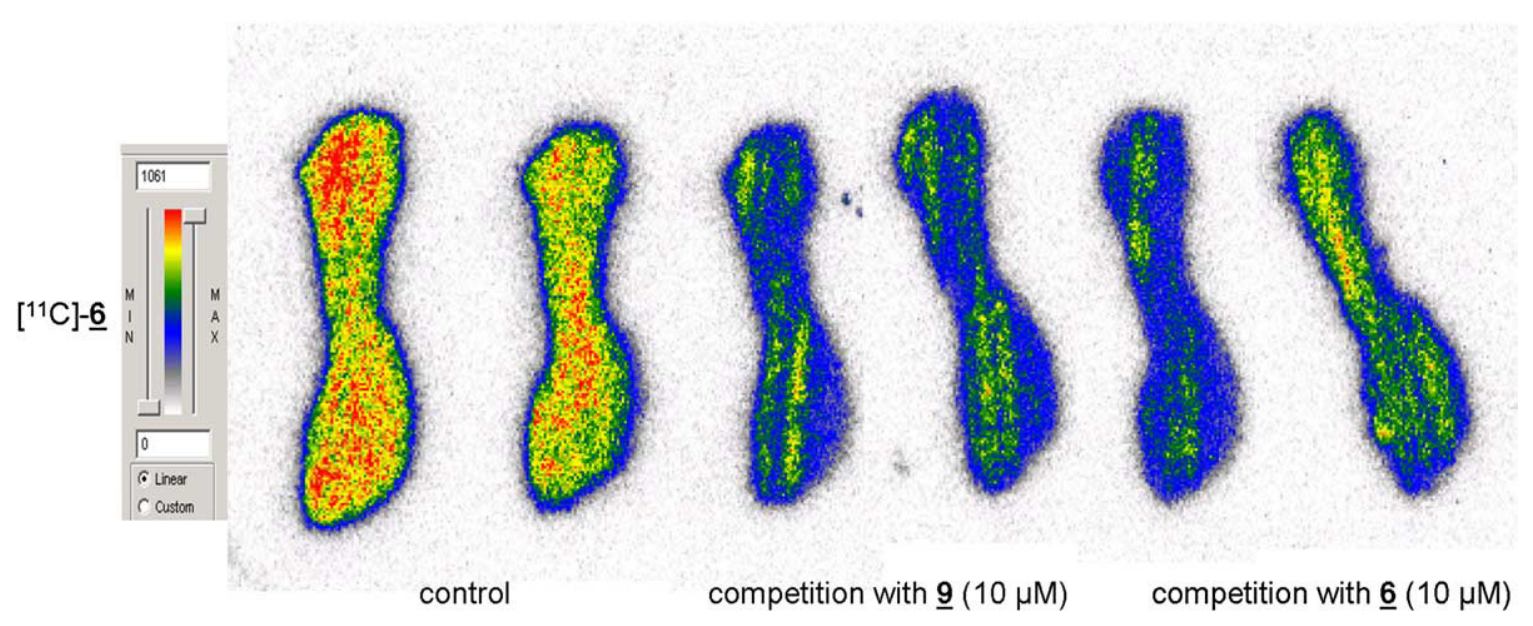

Fig. 2. In vitro autoradiography on mouse spleen. 


\section{Discussion}

We have, for the first time, demonstrated radiosynthesis of a high-affinity $\mathrm{CB}_{2}$ selective tracer which passes the BBB. Selection of the tracer was based on literature data describing several 2-oxoquinoline derivatives as high and selective $\mathrm{CB}_{2}$ receptor ligands (e.g., 10 [32]). We shortened the lipophilic carbon tail from a pentoxy to a butoxy group, which resulted in a decrease of 0.6 in calculated $\log P$ value with the aim to decrease non specific binding related to the lipophilicity of the tracer (Table 1).

Synthesis of the precursor 7 was quite challenging. Indeed, we tried several dealkylation agents without success; however, using lithium diphenylphosphide as dealkylation agent gave a selective cleavage of the methoxy group with a reasonable yield of $29 \%$. The yield using $\left[{ }^{11} \mathrm{C}^{\mathrm{C}} \mathrm{CH}_{3} \mathrm{I}\right.$ or $\left[{ }^{11} \mathrm{C}\right]$ methyl triflate was much higher than using $\left[{ }^{18} \mathrm{~F}\right] \mathrm{FEtBr}$ in the same labeling conditions. Note that the labeling procedure with F-18 was not yet optimised.

The affinity for the human $\mathrm{CB}_{2}$ receptor was in the low nanomolar range, thereby comparable to the affinity of the nonselective $\mathrm{CB}_{2} / \mathrm{CB}_{1}$ agonist $\mathrm{HU}-210(7.3 \pm 0.9)$ and the selective $\mathrm{CB}_{2}$ inverse agonist SR144528 (51.7 \pm 4.8$)$ when tested in the same conditions [33]. This indicates that $\mathbf{6}$ and $\mathbf{8}$ bind to the human $\mathrm{CB}_{2}$ receptor with high affinity. However, the fluoroethoxy group on position 7 seems to have a slightly negative effect on the affinity data when compared to a methoxy group in this position. Note that species differences in $\mathrm{CB}_{2}$ receptor binding data have been reported in the literature [34]. The studied molecules are structurally related to JTE-907 of which a higher mouse $\mathrm{CB}_{2}$ receptor affinity compared to the human has been reported (1.55 vs. $35.9 \mathrm{nM}$, respectively) [35]. One could therefore speculate the affinity for the mouse $\mathrm{CB}_{2}$ receptor to be higher for both tracers.

The ideal PSA value for molecules to penetrate the BBB is between 0 and 90 [36], whereas the $\log P$ is ideally between 1 and 3 [37]. Although the $\log P$ value of both tracers is higher than 3 , they both show good uptake in mouse brain $(1.7-1.8 \%$ of ID at $2 \mathrm{~min}$ pi) and efficient washout from brain.

Surprisingly, $\mathbf{8}$ seems to be less lipophilic than $\mathbf{6}$, as it is characterized by both a $\operatorname{lower} \log P$ value and a shorter retention time on the same analytical HPLC system. Therefore, background noise due to nonspecific binding to brain structures could be lower for $\left[{ }^{18} \mathrm{~F}\right]-\mathbf{8}$. This is confirmed by the biodistribution data where brain washout $(2 \mathrm{~min} /$ 60 min ratio ID) is higher for $\left[{ }^{18} \mathrm{~F}\right]-\mathbf{8}($ ratio $=18)$ compared to $\left[{ }^{11} \mathrm{C}\right]-6$ (ratio=4.3).

Both tracers are cleared from plasma by the hepatobiliary system as can be expected from their lipophilicity. They show persistent spleen uptake, an organ which is known for the high levels of $\mathrm{CB}_{2}$ expression [4]. The spleen uptake was found to be inhibited in vitro and in vivo by both $\mathbf{6}$ and the structurally unrelated $\mathrm{CB}_{2}$-specific compound 9, strongly indicating that the observed spleen uptake is $\mathrm{CB}_{2}$ specific. The rather slow uptake of $\left[{ }^{18} \mathrm{~F}\right]-8$ in bone suggests in vivo defluorination of the tracer rather than $\mathrm{CB}_{2}$-specific bone uptake.

Although both tracers are swiftly and extensively metabolised, this metabolism pattern does not seem to preclude $\mathrm{CB}_{2}$ receptor binding as indicated by the specific spleen uptake and retention.

As discussed in the Introduction, neuroinflammation results in marked $\mathrm{CB}_{2}$ receptor up-regulation, most likely due to up-regulation in activated microglial cells [9]. Therefore, these tracers could be useful for imaging the $\mathrm{CB}_{2}$ receptor in the described pathological conditions in the brain. Future work will include imaging of neuroinflammation in several animal models, e.g., such as for multiple sclerosis and amyotrophic lateral sclerosis followed by clinical studies.

\section{Conclusion}

We successfully synthesized two novel $\mathrm{CB}_{2}$ receptor PET tracers that show high affinity for the human $\mathrm{CB}_{2}$ receptor and in vivo specific $\mathrm{CB}_{2}$ receptor binding in the spleen of mice. Therefore, these tracers are promising candidates for the evaluation of the $\mathrm{CB}_{2}$ receptor in vivo and will be further investigated in preclinical and human studies.

\section{Acknowledgments}

We thank Peter Vermaelen and Ann Van Santvoort for their skillful help with the animal experiments.

\section{References}

[1] Van Laere K. In vivo imaging of the endocannabinoid system: a novel window to a central modulatory mechanism in humans. Eur J Nucl Med Mol Imaging 2007;34:1719-26.

[2] Horti AG, Fan H, Kuwabara H, Hilton J, Ravert HT, Holt DP, et al ${ }^{11} \mathrm{C}-J H U 75528$ : A radiotracer for PET imaging of $\mathrm{CB}_{1}$ cannabinoid receptors. J Nucl Med 2006;47:1689-96.

[3] Burns HD, Van Laere K, Sanabria-Bohorquez S, Hamill TG, Bormans G, Eng WS, et al. $\left[{ }^{18} \mathrm{~F}\right] \mathrm{MK}-9470$, A positron emission tomography (PET) tracer for in vivo human PET brain imaging of the cannabinoid-1 receptor. Proc Natl Acad Sci USA 2007;104:9800-5.

[4] Lynn AB, Herkenham M. Localization of cannabinoid receptors and nonsaturable high-density cannabinoid binding sites in peripheral tissues of the rat: implications for receptor-mediated immune modulation by cannabinoids. J Pharmacol Exp Ther 1994;268: $1612-23$.

[5] Onaivi ES. Neuropsychobiological evidence for the functional presence and expression of cannabinoid $\mathrm{CB}_{2}$ receptors in the brain. Neuropsychobiology 2006;54:231-46.

[6] Gustafsson K, Wang X, Severa D, Eriksson M, Kimby E, Merup M, et al. Expression of cannabinoid receptors type 1 and type 2 in nonHodgkin lymphoma: growth inhibition by receptor activation. Int $\mathrm{J}$ Cancer 2008;123:1025-33.

[7] Iuvane T, De Filippis D, Di Spiezio Sardo A. Selective $\mathrm{CB}_{2}$ upregulation in women affected by endometrial inflammation. J Cell Mol Med 2008;12:661-70.

[8] Steffens S, Veillard NR, Arnaud C, Pelli G, Burger F, Staub C, et al. Low dose oral cannabinoid therapy reduces progression of atherosclerosis in mice. Nature 2005;434:782-6. 
[9] Maresz K, Carrier EJ, Ponomarev ED, Hillard CJ, Dittel BN. Modulation of the cannabinoid $\mathrm{CB}_{2}$ receptor in microglial cells in response to inflammatory stimuli. J Neurochem 2005;95:437-45.

[10] Shoemaker JL, Seely KA, Reed RL, Crow JP, Prather PL. The CB cannabinoid agonist AM-1241 prolongs survival in a transgenic mouse model of amyotrophic lateral sclerosis when initiated at symptom onset. J Neurochem 2007;101:87-98.

[11] Benito C, Romero JP, Tolon RM, Clemente D, Docagne F, Hillard CJ, et al. Cannabinoid $\mathrm{CB}_{1}$ and $\mathrm{CB}_{2}$ receptors and fatty acid amide hydrolase are specific markers of plaque cell subtypes in human multiple sclerosis. J Neurosci 2007;27:2396-402.

[12] Ashton JC, Ratman RM, Nair SM, Sutherland BA, Glass M, Appleton I. Cerebral hypoxia-ischemia and middle cerebral artery occlusion induce expression of the cannabinoid $\mathrm{CB}_{2}$ receptor in the brain. Neurosci Lett 2007;412:114-7.

[13] Ramirez BG. Prevention of Alzheimer's disease pathology by cannabinoids: neuroprotection mediated by blockade of microglial activation. J Neurosci 2005;25:1904-13.

[14] Ofek O, Karsak M, Leclerc N, Fogel M, Frenkel B, Wright K. Peripheral cannabinoid receptor, $\mathrm{CB}_{2}$, regulates bone mass. Proc Nat Acad Sci USA 2006;103:696-701.

[15] Zheng D, Bode AM, Zhao Q, Cho Y, Zhu F, Ma W. The cannabinoid receptors are required for ultraviolet-induced inflammation and skin cancer development. Cancer Res 2008;68:3992-8.

[16] Lombard C, Nagarkatti M, Nagarkatti P. $\mathrm{CB}_{2}$ Cannabinoid receptor agonist, JWH-015, triggers apoptosis in immune cells: potential role for $\mathrm{CB}_{2}$-selective ligands as immunosuppressive agents. Clin Immunol 2007;122:259-70.

[17] Bai M, Sexton M, Stella N, Bornhop DJ. MBC94, A conjugable ligand for cannabinoid $\mathrm{CB}_{2}$ receptor imaging. Bioconjug Chem 2008;19. 988-92.

[18] Evens N, Bosier B, Lavey BJ, Kozlowski JA, Vermaelen P, Baudemprez L, et al. Labelling and biological evaluation of $\left[{ }^{11} \mathrm{C}\right]$ methoxy-Sch225336: a radioligand for the cannabinoid-type $2\left(\mathrm{CB}_{2}\right)$ receptor. J Nucl Med Biol 2008;35:793-800.

[19] Raitio KH, Savinainen JR, Vepsäläinen J, Laitinen JT, Poso A, Järvinen $T$, et al. Synthesis and SAR studies of 2-oxoquinoline derivatives as $\mathrm{CB}_{2}$ receptor inverse agonists. J Med Chem 2006;49: 2022-7.

[20] Mussinu J, Ruiu S, Mulè AC, Pau A, Carai MA, Loriga G, et al. Tricyclic pyrazoles: Part 1. Synthesis and biological evaluation of novel 1,4-dihydroindeno[1,2-c]pyrazol-based ligands for $\mathrm{CB}_{1}$ and $\mathrm{CB}_{2}$ cannabinoid receptors. Bioorg Med Chem 2003;11:251-63.

[21] Larsen P, Ulin J, Dahlstrom K, Jensen M. Synthesis of [C-11] iodomethane by iodination of [C-11]methane. Appl Radiat Isotopes 1997;48:153-7.

[22] Chitneni SK, Garreau L, Cleynhens B, Evens N, Bex M, Vermaelen P, et al. Improved synthesis and metabolic stability analysis of the dopamine transporter ligand $\left[{ }^{18}\right.$ F]FECT. Nucl Med Biol 2008;35: 75-82.

[23] Fritzberg AR, Whitney WP, Kuni CC, Klingensmith W. Biodistribution and renal excretion of ${ }^{99 \mathrm{~m}} \mathrm{Tc}-N-N^{\prime}$-bis-(mercaptoacetamido) ethylenediamine. Int J Nucl Med Biol 1982;9:79-82.

[24] Mitterhauser M, Toegel S, Wadsak W, Lanzenberger RR, Mien LK, Kuntner C, et al. Pre vivo, ex vivo and in vivo evaluations of $\left[{ }^{68} \mathrm{Ga}\right]$ EDTMP. Nucl Med Biol 2007;34:391-7.

[25] Chitneni SK, Serdons K, Evens N, Fonge H, Celen S, Deroose CM, et al. Efficient purification and metabolite analysis of radiotracers using high-performance liquid chromatography and on-line solidphase extraction. J Chromatogr A 2008;1189:323-31.

[26] Bradford MM. Rapid and sensitive method for quantitation of microgram quantities of protein utilizing principle of protein-dye binding. Anal Biochem 1976;72:248-54.

[27] Muccioli GG, Wouters J, Charlier C, Scriba GK, Pizza T, Di Pace P, et al. Synthesis and activity of 1,3,5-triphenylimidazolidine-2,4diones and 1,3,5-triphenyl-2-thioxoimidazolidin-4-ones: characterization of new $\mathrm{CB}_{1}$ cannabinoid receptor inverse agonists/antagonists. J Med Chem 2006;49:872-82.

[28] Cheng YC, Prusoff WH. Relationship between the inhibition constant (Ki) and the concentration of inhibitor which causes 50 per cent inhibition (IC50) of an enzymatic reaction. Biochem Pharmacol 1973; 22:3099-108

[29] Ireland RE, Walba DM. Demethylation of methyl aryl ethers: 4-ethoxy-3-hydroxybenzaldehyde. Org Synth 1977;56:44

[30] http://146.107.217.178/lab/alogps/start.html.

[31] http://www.daylight.com/meetings/emug00/Ertl/tpsa.html.

[32] Raitio KH, Savinainen JR, Nevalainen T, Järvinen T, Vepsäläinen J. Synthesis and in vitro evaluation of novel 2-oxo-1,2-dihydroquinoline $\mathrm{CB}_{2}$ receptor inverse agonists. Chem Biol Drug Des 2006;68:334-40.

[33] Stern E, Muccioli GG, Millet R, Goossens JF, Farce A, Chavatte P, et al. Novel 4-oxo-1,4-dihydroquinoline-3-carboxamide derivatives as new $\mathrm{CB}_{2}$ cannabinoid receptors agonists: synthesis, pharmacological properties and molecular modeling. J Med Chem 2006;49:70-9.

[34] Ashton JC, Wright JL, McPartland JM, Tyndall JDA. Cannabinoid $\mathrm{CB}_{1}$ and $\mathrm{CB}_{2}$ receptor ligand specificity and the development of $\mathrm{CB}_{2}$ selective agonists. Curr Med Chem 2008;15:1428-43.

[35] Iwamura H, Suzuki H, Ueda Y, Kaya T, Inaba T. In vitro and in vivo pharmacological characterization of JTE-907, a novel selective ligand for cannabinoid $\mathrm{CB}_{2}$ receptor. J Pharmacol Exp Ther 2001;296:420-5.

[36] Van de Waterbeemd H, Camenisch G, Folkers G, Chretien JR, Raevsky OA. Estimation of blood-brain barrier crossing of drugs using molecular size and shape, and H-bonding descriptors. J Drug Target 1998;6:151-65.

[37] Dischino DD, Welch MJ, Kilbourn MR, Raichle ME. Relationship between lipophilicity and brain extraction of C-11 labelled radiopharmaceuticals. J Nucl Med 1983;24:1030-8. 